\title{
Expertní informační systém NAVAROSO
}

\section{PŘEMYSL SOLDÁN, JAROSLAV ROČEK}

Klíčová slova: havarijní znečištění - teroristické útoky na vodní zdroje -

kriminální činnost zaměřená na vodní zdroje - expertní havarijní informační systém

\section{SOUHRN}

Př́spěvek podává informaci o tvorbě expertního informačního systému NAVAROSO, budovaného pro potřeby složek aktivních při vzniku havarijní situace na vodách. Systém poskytuje křížově provázané údaje, potřebné pro rychlé získávání informací o možných příčinách zhoršení jakosti vod, postupech k určení typu znečištění a odhadu jeho šíření ve vodoteči. Tím umožní zefektivnit ochranu vod jak v oblasti mitigace negativních vlivů znečištění rychlejší detekcí jeho prríčin, tak v prevenci možného znečištování přesnější a rychleji dostupnou informací o jeho potenciálních zdrojích v povodí. $V$ textu je stručně popsána jeho stavba, funkce, struktura informací, uložených v jeho databázi a také modul, umožňující výpočet chování znečištění v toku.

\section{Návrh základních datových zdrojů pro expertní systém}

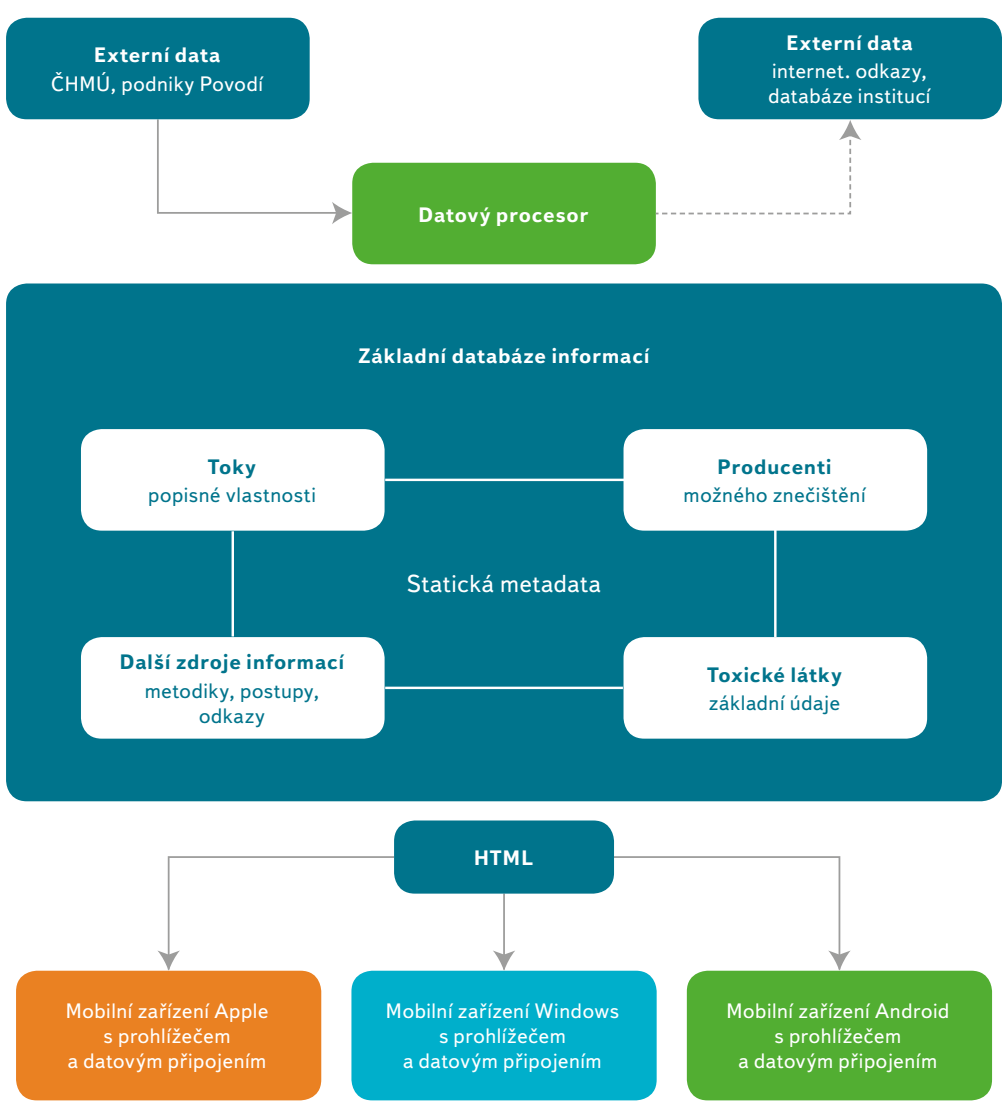

Obr. 1. Základní datové zdroje pro expertní systém

Fig. 1. Basic data sources for expert system

\section{ÚVOD}

V důsledku provozních havárií dochází relativně často k menším či významnějším únikům toxického znečištění povrchových vod. Tato kontaminace recipientů může mít fatální následky pro jejich oživení. Tak tomu bylo v evropském měřítku např́klad při haváriích v Sandozu v Basileji v roce 1986 [1, 2], v Baia Mare $\checkmark$ roce 2000 [3, 4] nebo $v$ Ajce $v$ roce 2010 [5-7].

Současnou bezpečnostní situaci rovněž charakterizuje zvýšené riziko možného zneužití toxických látek pro teroristické či kriminální účely, a to včetně potenciálních útoků na zdroje vod. Danou situaci podrobně charakterizuje dokument Ministerstva životního prostředí ČR „Koncepce environmentální bezpečnosti 2016-2020 s výhledem do roku 2030“ v kapitole 3. Environmentální bezpečnost v ČR z hlediska zdrojů rizik antropogenního původu [8].

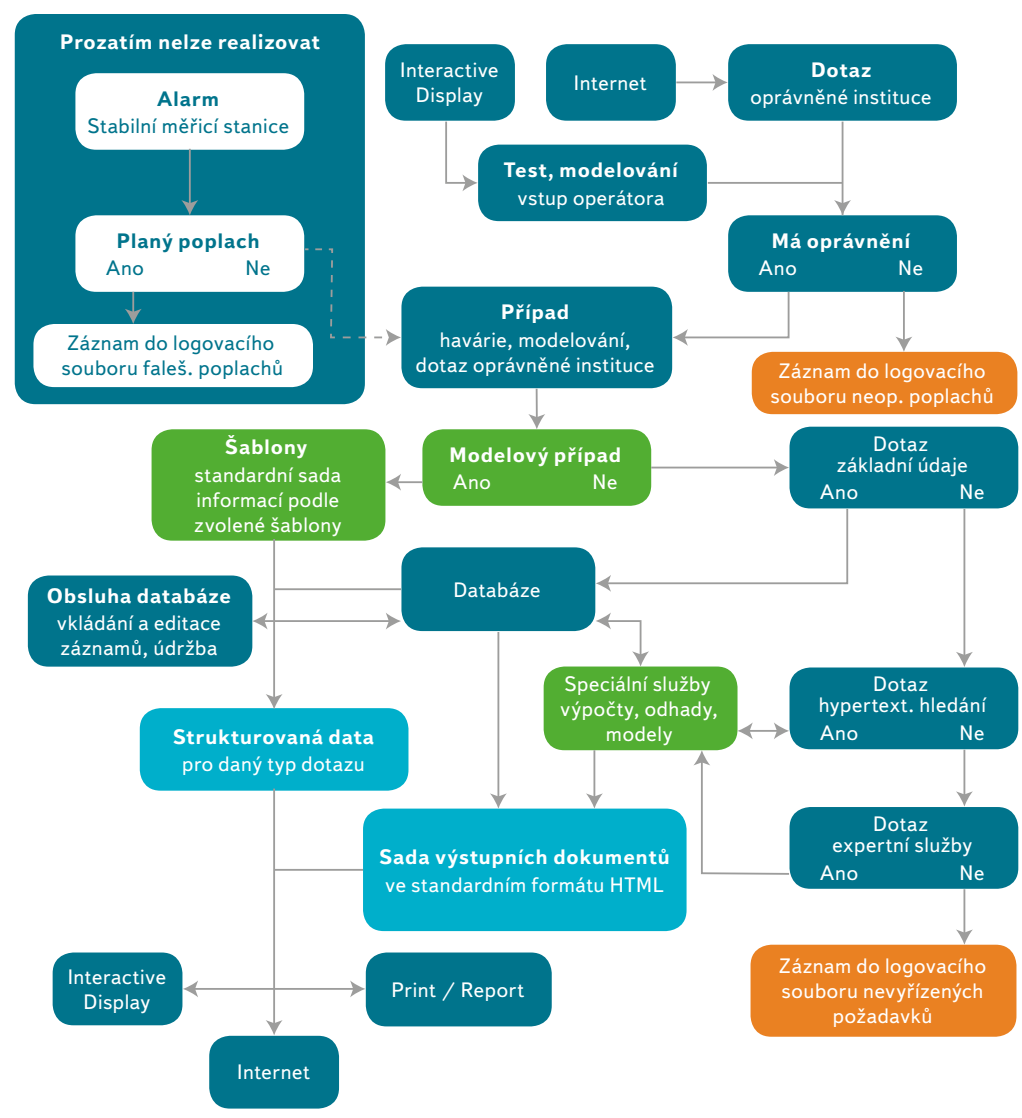

Obr. 2. Základní procesy při vyřizování požadavků na systém Fig. 2. Basic processes in dealing with system requirements 
V současné době tato rizika zvyšuje ještě další faktor. Tím jsou stále častěji se opakující období sucha, které má vliv na vodnost toků. Minimalizován je totiž možný zmírňující vliv naředění znečištění.

Př́klady významných vodohospodářských havárií od roku 1964 uvádí na svých webových stránkách Česká inspekce životního prostředí [9]. Zde je například od roku 2010 uvedeno 24 havárií tohoto typu. I pres skutečnost, že k havarijnímu znečištění vod dochází relativně často, v České republice zatím neexistuje funkční a dostatečně efektivní systém včasného varování a následné detekce přičin mimořádných situací vyvolaných havarijním znečištěním vod.

\section{SYSTÉM VČASNÉHO VAROVÁNÍ}

Systém včasného varování by měl co nejcitlivěji reagovat na změnu jakosti vod, způsobenou havarijním znečištěním, teroristickou nebo kriminální činností.

Mezinárodní strategie pro snižování rizika katastrof OSN definuje systém včasného varování jako sadu postupů potřebných pro generování a šiření včasných a užitečných varovných informací, které umožní jednotlivcům, komunitám a institucím, ohroženým nebezpečím, připravit se a náležitě jednat v čase, dostatečném k redukování možných škod a ztrát [10].
Problematice systému včasného varování v oblasti havarijního znečištění řek se věnovala řada autorů, výčet významnějších publikací je uveden v prehledu literatury [11-17].

Obsáhlý rozbor metod sledování a hodnocení kvality vod, včetně metod použitelných pro detekci prípadů havarijního znečištění podává studie, editovaná Chapmanovou [18].

Přehled, zásady výstavby, provozování a hodnocení systémů včasného varování v různých částech životního prostředí (voda, půda, vzduch) a také v oblasti humanitárních katastrof podává ve své práci Quansah a kol. [19]. V obecném závěru této stati je konstatováno, že současná úroveň systémů včasného varování v oblasti náhlých změn kvality (tedy i pro havarijní znečištění) je nedokonalá a je vysoce žádoucí vytvořit plně integrované a vysoce efektivní systémy.

Dané závěry také platí pro Českou republiku. Naposledy byl tento fakt diskutován na mezinárodní úrovni v prípadě havarijního úniku kyanidů z Draslovky v Kolíně $\checkmark$ roce 2006 [20]. Protože se jednalo o havárii s možným dopadem na povodí sousedícího státu, měla být neprodleně informována německá strana. Varovná informace však byla odeslána až s devítidenním zpožděním. Tato situace se dodnes výrazně nezlepšila. Lze konstatovat, že u nás zatím neexistuje funkční a dostatečně efektivní systém včasného varování pro prípady mimořádných situací na vodách způsobených jejich znečištěním. Chybí podrobně propracovaná strategie postupu rychlé detekce účinků havárie na vodní ekosystémy i metodiky automatických i následných

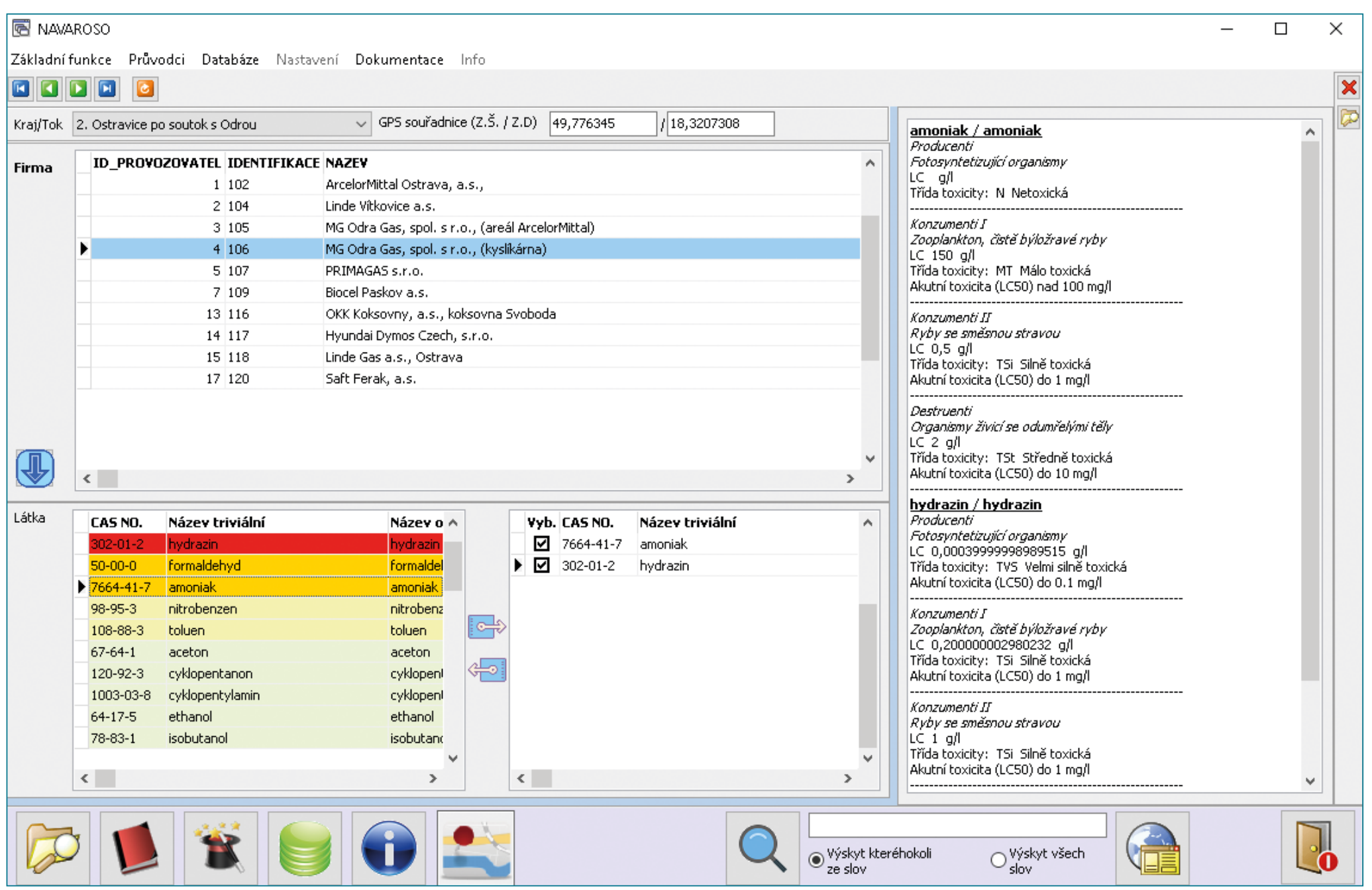

Obr. 3. Printscreen prríkladu křižového vyhledávání

Fig. 3. Printscreen of example of cross-search 


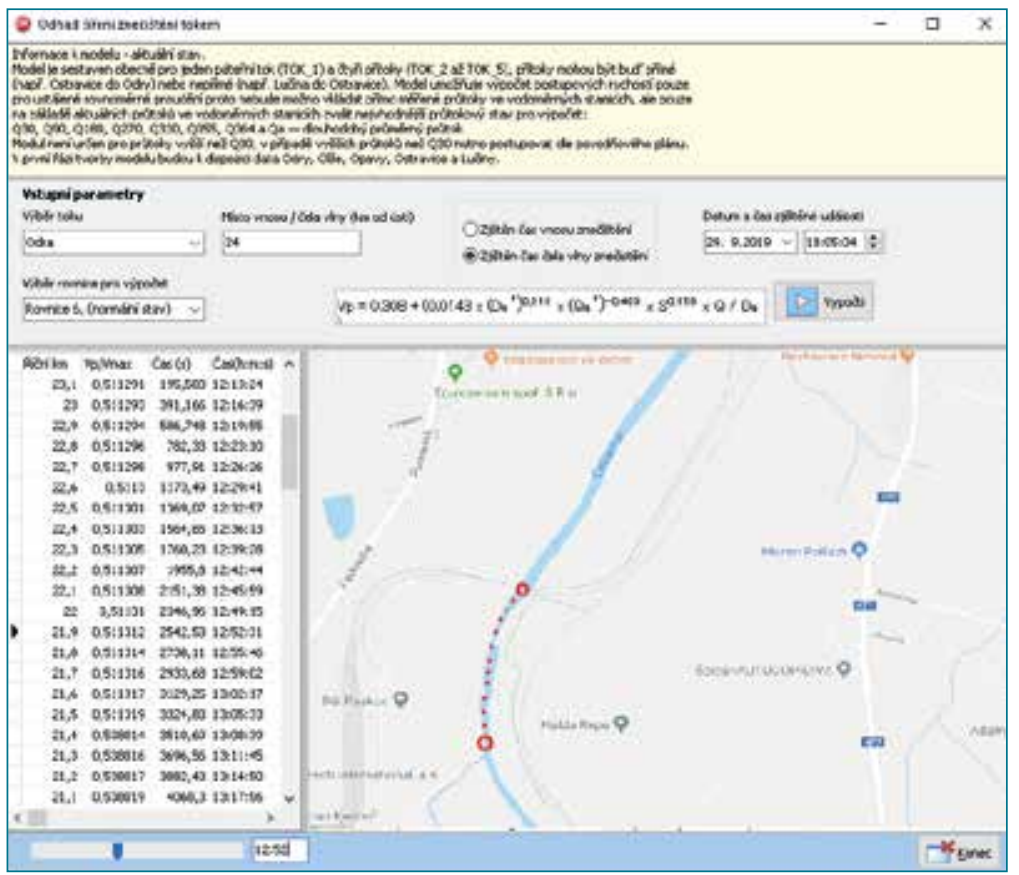

Obr. 4. Šíření havarijního znečištění tokem

Fig. 4. Spreading of accidental pollution by flow

terénních analýz zaměřených na rychlé určení původce havarijního zhoršení stavu vod. Pro nápravu této nežádoucí situace byly navrženy dva výzkumné projekty, financované z grantů Technologické agentury České republiky - projekt Vývoj nástrojů včasného varování a reakce v oblasti ochrany povrchových vod (NAVARO), jehož hlavním výstupem byla Metodika postupu vyhlašování havarijních stavů na tocích [21], certifikovaná Ministerstvem životního prostředí, popisující nástroje rychlé detekce vzniku a př́čin havárií, teroristických útoků či kriminální činnosti s dopadem na kvalitu povrchových vod (řešeno v letech 2011 až 2014), a navazující projekt zabývající se výstavbou expertního informačního systému NAVAROSO (řešení zahájeno v roce 2017). Tento př́spěvek podává stručnou informaci o poznatcích a výsledcích získaných prí řešení problematiky výstavby expertního systému.

\section{EXPERTNÍ INFORMAČNÍ SYSTÉMY}

Problematika softwarové podpory (expertních systémů) pro zvýšení efektivity činností při výskytu mimořádných situací se výrazněji obecně diskutuje $\checkmark$ odborných pracích od druhé poloviny osmdesátých let minulého století např. [22-24]. I když jsou poznatky, závěry a doporučení těchto statí poplatné úrovni rozvoje komputerizace dané doby, jejich obecná platnost přetrvává.

Krizovým systémům reakce pro havárie (Emergency Response System for Pollution Accidents) $\vee$ chemických průmyslových parcích $\vee$ Číně se věnují Duan a He [25]. Ti uvádějí základní požadavky na výstavbu těchto systémů (viz tabulku 1).

Podpůrným systémům, které usnadní detekci neznámého znečištění, a tím umožní zvýšit efektivitu havarijních opatření pro prípady znečištění stojatých vod, se věnují Chen a kol. [26]. Ti popisují praktické zkušenosti s užitím sytému, který integruje data získaná z on-line monitoringu biologické jakosti vod s vysoce výkonnými matematickými modely pro výpočet změn jakosti vod. Na základě získaných zkušeností doložených príklady užití na dvou vybraných vodních nádržích konstatují, že tento systém přináší velmi užitečné informace zkvalitňující práci havarijních složek.

Rozsáhlý rozbor problematiky včasného varování pro případy havarijního znečištění vod podává úvodní studie Water quality early warning system [27]. Zde je zmiňována nutnost vytvoriit „základní kuchařku“ (Basic CookBook) IT systém, obsahující informace a návody pro řešení havarijních situací. Těmto potřebám má plně vyhovovat databázový expertní systém NAVAROSO. Ten se má stát efektivním informačním nástrojem systému včasného varování v České republice $v$ oblasti ochrany vod pred havarijním znečištěním. Aby totiž mohly

Tabulka 1. Základní požadavky na výstavbu krizových systémů reakce

Table 1. Basic requirements for the construction of crisis response systems

\section{Požadovaná funkce}

\section{Zajištění požadované funkce}

Efektivní sběr informací, analýza a prognóza (včetně monitorovacího systému)

Shromažd’ování dat z krizových systémů reakce, jejich analýza a porovnávání

Adresář složek, aktivních při řešení havarijní situace

Databáze dostupného personálního a materiálního vybavení

Účelově zaměřená informační základna

Právní a bezpečnostní předpisy a nařízení, kodifikace, odkazy a mapové podklady

Komunikační podpora

Sítový robustní a mobilní kanál pro bezpečnou komunikaci

Podpora rozhodovacího procesu

Expertní systém jako podpora rozhodovacího procesu

Podpora sledování reakce

Sledování aktuálního rozmístění složek, zdrojů a průběhu

Multimediální podpora (včetně geografických informačních systémů, fotografických systémů a bezdrátových sítí)

Vizualizační nástroje pro prezentaci, rozhodovací proces a komunikaci

Podpora zabezpečení

Řízení zabezpečeného prístupu a informačního toku

Podpora odolnosti proti chybám a ukládání redundantních dat

Zálohování dat, distribuce uložených dat, vyvážení zatížení a sledované (zrcadlené) horké servery (mirrored hot servers) 


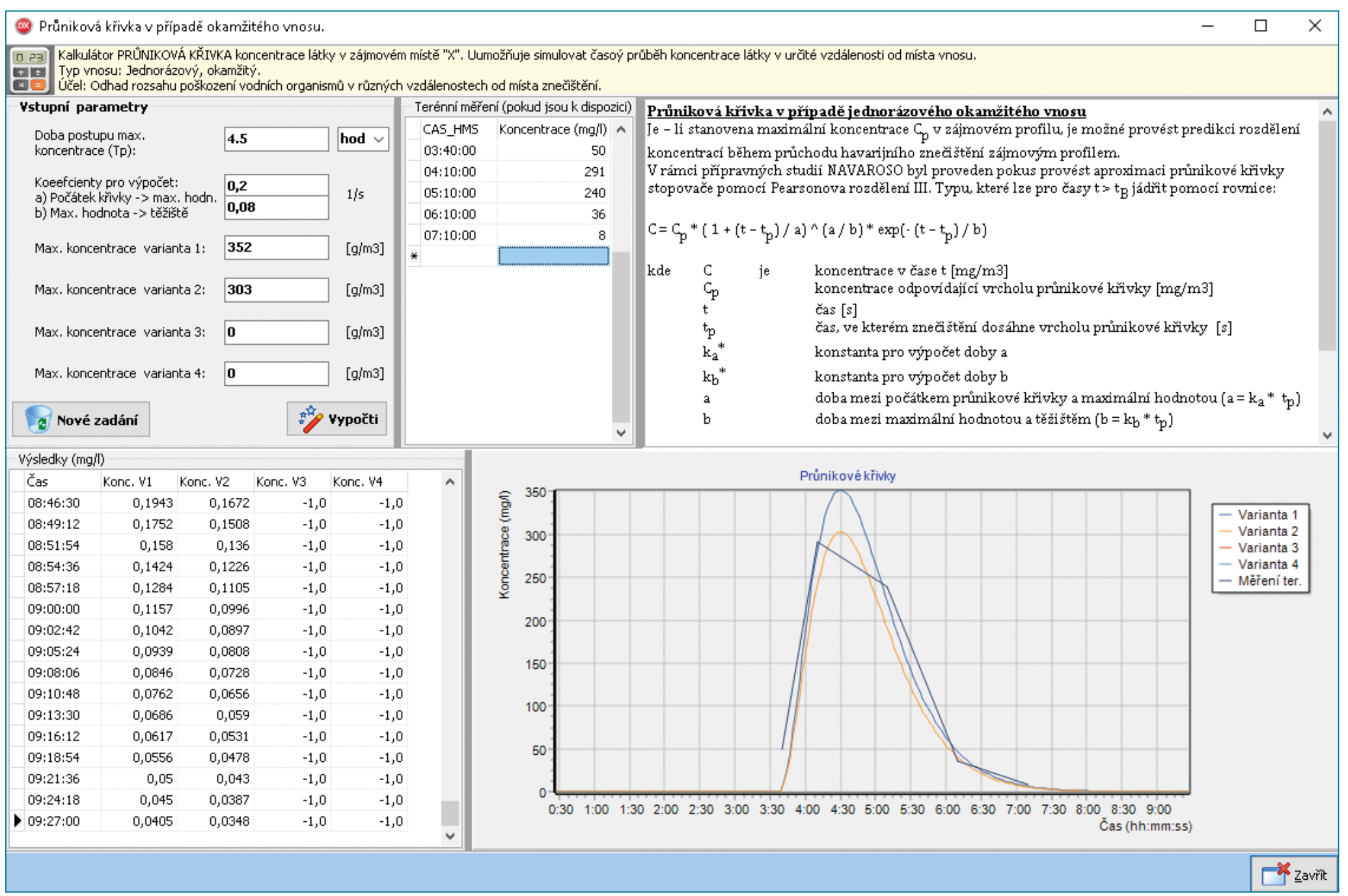

Obr. 5. Printscreen zpětné analýzy průběhu znečištění

Fig. 5. Printscreen of reverse analysis of contamination course

složky aktivní při mimořádných situacích spojených s náhlým (havarijním) snížením biologické jakosti vod účinně reagovat, musí být vybaveny vhodnými nástroji pro rychlou indikaci zhoršení jakosti vod a pro následné analýzy, zaměrené na detekci jeho prričin. V současné době takový systém, poskytující širokou škálu informací v dané oblasti, není dostupný jak u nás, tak v zahraničí.

\section{METODA ŘEŠENÍ}

Při výstavbě expertního systému NAVAROSO jsou respektovány zásady dané výše uváděnou Metodikou postupu vyhlašování havarijních stavů na tocích [21]. Systém poskytuje křížově provázané údaje potřebné pro rychlé získávání informací o možných příčinách zhoršení biologické jakosti vod, postupech k určení typu znečištění a odhadu jeho šiření ve vodoteči. Databázový systém je doplněn modulem pro odhad chování znečištění v recipientu. Tím nově vyvinutý expertní systém umožňuje:

— zefektivnit postup rychlého a prokazatelného nalezenízdroje kontaminace vod (tato funkce má velký význam pro prevenci možného znečištování),

- zrychlit a zpřesnit odhad míry kontaminace, a tím umožnit i predikci dalšího vývoje havárie,
- včasné varování po proudu umístěných území a odběratelů vody,

— včasné splnění mezinárodních oznamovacích povinností ČR,

- poskytnout přesnější podklady pro včasné naplánování účinné mitigační akce. Komplexní expertní systém v oblasti ochrany vodních toků, kombinující statická metadata s modelovacím a predikčním modulem, který by byl dostupný na téměř všech typech zařizení s připojením k internetu, nebyl doposud v zahraničí ani u nás vyzkoušen a realizován. Aby bylo minimalizováno riziko vytvoření nevhodné struktury poskytovaných dat nebo nevhodný způsob jejich prezentace, byly v průběhu řešení projektu svolávány schůzky s potenciálními koncovými uživateli (složky IZS, ČIŽP, vodoprávní úřady a správci povodí), na kterých byl diskutován postup prací a formy výstupů řešení, aby výsledný produkt co nejlépe odpovídal jejich potřebám. Plánován je také zkušební provoz expertního systému s dobrovolnou účastí vybraných koncových uživatelů.

\section{Realizace databáze}

Databáze byla fyzicky realizována v prostředí databázového stroje FIREBIRD. Základní datové zdroje pro expertní systém jsou uvedeny na obr. 1 . 
Nad databází je vytvořen informační systém základního dotazovacího a servisního software, který dokáže poskytnout křižově vyhledávané informace o subjektech, znečištujících látkách a tocích, vhodných postupech vzorkování a terénních analýz a také postupech orientačního určení př́čin poškození ichtyofauny. Procesní diagram je zobrazen na obr.2.

Systém umožňuje editaci a vkládání nových údajů do databáze. Je schopen pracovat i s odkazy na základní literární zdroje (texty, odkazy na internetové články). Je vytvořen základ pro hypertextové vyhledávání v primárních informačních zdrojích. Další funkcí je projekce uložených metadat do reálného prostředí digitalizovaných map, což usnadňuje orientaci v terénu složkám aktivním při mimořádných situacích na tocích. Uživatelské rozhraní systému je realizováno v programovacím prostředí Embarcadero Delphi XE10 a HTML Builder 5 .

V současné době databáze disponuje údaji o potenciálních znečištovatelích (v současnosti údaji o 400 látkách u 200 významných znečištovatelů v dílčích povodích ČR).

Pro tyto potřeby byl jako výchozí podklad použit Přehled významných znečištujících látek v povodích podle krajů vypracovaný Výzkumným ústavem vodohospodářským T. G. Masaryka, v. v. i., verze z roku 2018 [28]. Tento přehled uvádí významné znečištovatele, údaje o relevantních polutantech, včetně informací o jejich ekotoxicitě. Údaje o jednotlivých znečištovatelích jsme doplnili specifikací jejich polohy v povodí pomocí GPS souřadnic. Dalším zdrojem informací je Integrovaný systém plnění ohlašovacích povinností (ISPOP), databáze provozovaná Českou agenturou životného prostředí (CENIA) na základě pověření Ministerstva životního prostředí ČR. Validaci dat zajistily při pořizování zmíněné instituce. I přes tuto skutečnost jsme provedli ověření aktuální existence a aktivity firem v databázi uložených. Další aktualizace je plánována hlavně ze zdrojů ISPOP, vyžádaných u CENIA. Printscreen príkladu křížového vyhledávání je uveden na obr. 3.

Dalšími zdroji informací, dostupných použitím expertního systému, jsou Metodika postupu vyhlašování havarijních stavů na tocích [20], vzory protokolů pro záznam o havárii a pro odběr vzorků, přehled metod analýz, vhodných pro terénní použití, Metodický postup vyšetřování havarijních úhynů ryb [29] a Klíč projevů otrav ryb, obsahující ekotoxikologické informace a prípadové studie pro vybrané významné příčiny poškození ichtyofauny recipientu.

Dostupnost základních funkcí systému v terénu zajištuje internetové rozhraní, které Ize použít na libovolném mobilním zařízení se zabudovaným internetovým prohližečem a datovým připojením.

\section{Matematický modul}

Původním záměrem v návrhu projektu NAVAROSO bylo doplnění expertního systému modulem pro výpočet polohy možného zdroje znečištění a hrubý odhad šírení tohoto znečištění tokem z údajů kontinuálního monitoringu biologické jakosti vod. Modelově měly být tyto odhady prováděny na základě výstupů kontinuálního monitoringu jakosti povrchových vod z přístrojů, umístěných na dvou vybraných říčních profilech. Podnik Povodí Odry, na jehož stanicích byly prístroje umístěny, však neočekávaně vypověděl spolupráci $\checkmark$ této oblasti a dané prístroje musely být na jeho žádost ze stanic odstraněny. Protože však zejména zástupci hasičského záchranného sboru považují informace o šiření znečištění v toku za velmi potřebné pro zvýšení efektivity své činnosti v prípadě havarijního zásahu, byly pưvodně plánované práce na modulu pro výpočet účelově modifikovány. Zásadní změna spočívá v tom, že model bude možno použít přímo při řešení aktuálního havarijního stavu na libovolném úseku vodního toku oproti původnímu záměru, který byl zaměřený pouze na zpětnou analýzu havárie na základě záznamu v měřicí stanici. Zároveň byl původní model, koncipovaný pouze pro havárie způsobené rozpustnými látkami, rozšířen o simulaci šíření ropných látek v toku, vzhledem k tomu že převážná část havárií bývá způsobena těmito látkami. Printscreen na obr. 4 ukazuje výpočet postupu znečištění v toku. Printscreen uvedený na obr. 5 ukazuje zpětnou analýzu průběhu znečištění.

\section{ZÁVĚR}

NAVAROSO je expertní informační systém, který kombinuje statická metadata s modelovacím a predikčním modulem. Tím poskytuje vysoce komplexní informace, využitelné při řešení mimořádných situací, spojených s havarijním znečištěním vod. Pro složky aktivní při havarijních zásazích (složky IZS, ČlŽP, vodoprávní úřady a správci povodí) bude dostupný téměř na všech typech zařízení s prípojením k internetu, tedy jak v rídicích centrech zásahu, tak prímo v terénu (místě zásahu). Tím se stává nástrojem, který významně zvyšuje efektivitu činnosti výše zmíněných složek. Tento názor se opírá o vyjádření zamýšlených koncových uživatelů.

\section{Poděkování}

$\checkmark$ textu prezentované poznatky a výsledky byly získány $v$ rámci rešení projektu Expertní systém NAVAROSO (evidenční čislo projektu TH02030142), financovaného Technologickou agenturou ČR.

\section{Literatura}

[1] GÜTTINGER, H. and STUMM, W. An Analysis of the Rhine Pollution caused by the Sandoz Chemical Accident, 1986. Interdisciplinary Science Reviews, 1992, vol. 17, No. 2, p. 127-136.

[2] GIGER, W. The Rhine red, the fish dead-the 1986 Schweizerhalle disaster, a retrospect and longterm impact assessment. Environ. Sci. Pollut. Res., 2009, vol. 16, p. 98-111.

[3] Anonymous. Spill of liquid and suspended waste at the Aurul S.A. retreatment plant in Baia Mare. UNEP/ OCHA, Geneva, 2000

[4] SOLDÁN, P., PAVONIČ, M., BOUČEK, J., and KOKĚS, J. Baia Mare Accident - Brief Ecotoxicological Report of Czech Experts. Ecotoxicology and Environmental Safety, 2001, 49, p. 255-261.

[5] GELENCSÉR, A., KOVÁTS, N., TURÓCZI, B., ROSTÁSI, A., HOFFER, A. et al. The Red Mud Accident in Ajka (Hungary): Characterization and Potential Health Effects of Fugitive Dust. Environ. Sci. Technol., 2011 [vid. 10. 3. 2018]. Dostupné z: http://mposfai.hu/Gelencser_redmud_dust_EST_2011.pdf

[6] RUYTERS, S., MERTENS, J., VASSILIEVA, E., DEHANDSCHUTTER, B., POFFIJN, A., and SMOLDERS, $\mathrm{E}$. The red mud accident in Ajka (Hungary): Plant toxicity and trace metal bioavailability in red mud contaminated soil. Environ. Sci. Technol., 2011, vol. 45, No. 4, p. 1616-22. Dostupné z: doi: 10.1021/ es104000m. Epub 2011 Jan 4.

[7] MAYES, W.M., BURKE, I.T., GOMES, H.I., ANTON, Á.D., MOLNÁR, M., FEIGL. V., and UJACZKI, É. Advances in Understanding Environmental Risks of Red Mud After the Ajka Spill, Hungary. Journal of Sustainable Metallurgy, 2016, vol. 2, No. 4, p. 332-343.

[8] Anonymous. Koncepce environmentálni bezpečnosti 2016-2020 s výhledem do roku 2030. MŽP ČR, 2015 [vid. 20. 1. 2017]. Dostupné z: https://www.mzp.cz/C1257458002F0DC7/cz/environmentalni_ bezpecnost/\$FILE/OKR-koncepce_environmentalni_bezpecnosti_2016_2020-20160606.pdf.

[9] Anonymous. Př́klady významných vodohospodářských havárií od r. 1964 [vid. 20. 8. 2019]. Dostupné z: https://www.mzp.cz/C1257458002F0DC7/cz/environmentalni_bezpecnost/\$FILE/OKR-koncepce_ environmentalni_bezpecnosti_2016_2020-20160606.pdf

[10] Anonymous. UNISDR Terminology on Disaster Risk Reduction. OSN a UNISDR, Ženeva, 2009 [vid. 10. 2. 2017]. Dostupné z: http://www.unisdr.org/files/7817_UNISDRTerminologyEnglish.pdf.

[11] VAN DER SCHALIE, W. Can Biological Monitoring Early Warning Systems Be Useful Detecting Toxic Materials in Water? In: POSTON, T. and PURDY, R. (eds.) Aquatic Toxicology and Environmental Fate: Ninth Volume. ASTM International, 1986, p. 107-121.

[12] KRAMER, K.J.M. and BOTTERWEG, J. Aquatic biological early warning systems. An overview, In: JEFFREY, D.W. and MADDEN, B. Bioindicators and environmental management. Academic Press, London, 1991, p. 95-126.

[13] BALDWIN, I.G. and KRAMER, K.J.M. Biological early warning systems (BEWS). In: KRAMER, K.J.M. Biomonitoring of coastal waters and estuaries. CRC Press, Boca Raton, 1994, p. 1-27. 
[14] GUNATILAKA, A. and DIEHL, P. A brief review of chemical and biological continuous monitoring of rivers in Europe and Asia. In: BUTTERWORTH, F.M. et al. Biomonitors and biomarkers as indicators of environmental change 2. Kluwer Academic/Plenum Publishers, New York, 2000, p. 9-28.

[15] SCHNEIDER, X. D66: Best practice in guidance for water body monitoring. Xpro-Consulting, Cyprus, 2001.

[16] GRAYMAN, W.M., DEININGER, R.A., and MALES, R.M. Design of early warning and predictive sourcewater monitoring systems. AWWA Research Foundation and American Water Works Association, Denver, 2001.

[17] GUNATILAKA, A. and DREHER, J. Use of real-time data in environmental monitoring: current practices. Water Science \& Technology, 2003, vol. 47, No. 2, p. 53-61.

[18] CHAPMAN, D. (ed.) Water Quality Assessments: A Guide to Use of Biota, Sediments and Water in Environmental Monitoring. 1996, $2^{\text {nd }}$ edition [vid. 8. 2. 2017]. Dostupné z: http://www.who.int/water sanitation_health/resourcesquality/watqualassess.pdf

[19] QUANSAH, J.E., ENGEL, B., and ROCHON, G.L. Early Warning Systems: A Review. Journal of Terrestria Observation, 2010, vol. 2, No. 2, article 5 [vid. 2. 3. 2017]. Dostupné z: http://docs.lib.purdue.edu/cgi/ viewcontent.cgi?article $=1072 \&$ context $=$ jto

[20] WHITE, J. Cyanide leak unreported for days. 2006 [vid. 8. 2. 2007]. Dostupné z: www.thepraguepost. com/articles/2006/01/25/cyanide-leak-unreported-for-days.php

[21] SOLDÁN, P. a kol. Metodika postupu vyhlašování havarijnich stavů na tocích. Ostrava: VúV TGM, 2014

[22] FEDRA, K. and OTWAY, H.J. Advanced Decision-Oriented Software for the Management of Hazardous Substances: Part III - Decision Support and Expert Systems: Uses and Users. IIASA Collaborative Paper. IIASA Laxenburg, Austria, 1986, CP-86-014. [vid. 8. 3. 2017]. Dostupné z: http://pure.iiasa.ac.at/2951/1/WP-87 101.pdf

[23] GASS, S.R., BHASKER, S., and CHAPMAN, R.E. Expert Systems and Emergency Management: An Annotated Bibliography. National Bureau of Standards Special Publication 728. U.S. Government Printing Office, Washington, 1986, Library of Congress Catalog Card Number: 86-600591.

[24] LIEBOWITZ, J. The Handbook of Applied Expert System. CRC Press, 1997. ISBN 9780849331060 - CAT\# 3106.

[25] DUAN, W. and HE, B. Emergency Response System for Pollution Accidents in Chemical Industrial Parks, China. Int. J. Environ. Res. Public Health, 2015, 12, 7868-7885. Dostupné z: doi:10.3390/ ijerph120707868.

[26] CHEN, Q., MA, J., WANG, Z., and HUANG, G. Biological early warning and emergency management support system for water pollution accident. Trans. Tianjin Univ., 2012, 18, p. 201-205. Dostupné z: doi: 10.1007/s12209-012-1662-4.

[27] Anonymous. Water quality early warning system / On transboundary watercourses of the Tisza river basin - Initial study. 2014 [vid. 9. 3. 2017]. Dostupné z: https://www.danubewaterquality.eu/uploads/ mod_files/WQM-EWS_part-1-4_EN_v2.0_.pdf

[28] Anonymous. Prehled významných znečištujicích látek v povodich podle krajů. Ostrava: VúV TGM, 2018

[29] SVOBODOVÁ, Z., MÁCHOVÁ, J., CHLOUPEK, P. a VEČEREK, V. Metodický postup vyšetřováníhavarijních úhynů ryb. Edice metodik 107. České Budějovice: Jihočeská univerzita, Fakulta rybářství a ochrany vod, 2011. ISBN 978-80-87437-25-4

\section{Autoři}

RNDr. Přemysl Soldán, Ph.D. ${ }^{1}$

凶premysl.soldan@vuv.cz

RNDr. Jaroslav Roček

凶jardarocek@gmail.com

'Výzkumný ústav vodohospodářský T. G. Masaryka, v. v. i., pobočka Ostrava

Příspěvek prošel lektorským řízením.

\section{NAVAROSO EXPERT INFORMATION SYSTEM}

\section{SOLDAN, P.', ROCEK, J.}

${ }^{1}$ TGM Water Research Institute, p.r.i., Ostrava Branch

Keywords: accidental pollution - terrorist attacks on water resources criminal activities focused on water resources expert emergency information systems

The article provides information on the development of the NAVAROSO expert information system built for the needs of components active in the event of an emergency situation on the water. It provides the cross-linked data needed to quickly obtain information on the possible causes of deterioration in water quality, procedures to determine the type of pollution and estimate its spread in the watercourse. This will make water protection more effective both in mitigation of the negative effects of pollution by faster detection of its causes and in the prevention of possible pollution by more accurate and readily available information on its potential sources in the river basin. The text briefly describes its structure, function, structure of information stored in its database as well as a module allowing the calculation of the behaviour of pollution in the flow. 